\begin{tabular}{ll}
\hline \hline MINING AND METALLURGY INSTITUTE BOR & ISSN: 2334-8836 (Štampano izdanje) \\
UDK: 622 & ISSN: 2406-1395 (Online) \\
\hline \hline
\end{tabular}

Kristina Vojvodić, Ljiljana Nikolić Bujanovic ${ }^{* *}$, Sanja Mrazovac Kurilic ${ }^{* * * *}$, Novica Staletovic ${ }^{* * * *}$

\title{
APPLICATION OF ECOFRENDLY OXIDANT FERRATE(VI) IN THE METALLURGICAL PROCESSES OF COPPER EXTRACTION*****
}

\begin{abstract}
This works deals with investigation the efficiency of sodium ferrate, $\mathrm{Na}_{2} \mathrm{FeO}_{4}$, obtained by the electrochemical oxidation, as coagulation and flocculation agent for purification of wastewater from the electrolytic refining process from the Bor Copper Refinery and Copper Smelter Plant of the Mining and Smelting Combine Bor. Removal of heavy metals and selenium by barium ferrate in aqueous solutions could be possible up to: $100 \%$ for $\mathrm{Cu}, 97.18 \%$ for $\mathrm{As}, 98.37 \%$ for Sb and $6.06 \%$ for Se using ferrate $(V I)$ in the ratio $M: F e(V I)=1: 12$.

Also, the efficiency dependence of copper sulphide ore leaching from concentrate by the oxidation of copper sulfide and chalcopyrite with ferrate(VI) on the sulphuric acid concentration was investigated in this work. It is found that leaching of copper from vthe copper sulfide concentrate, carried out by ferrate(VI), proceeds easily due to the efficient oxidation of sulfide and sulfur, in respect of the classical acid process that usually needs the addition of strong oxidant, such as oxygen or hydrogen peroxide, to increase the process productivity.
\end{abstract}

Keywords: ferrate(VI), chalcopyrite, hydrometallurgical, wastewater, oxidation

\section{INTRODUCTION}

The first descriptions of ferrate(VI), $\mathrm{Fe}(\mathrm{VI})$, are given in 1702 [1]. In 1715, Stahl noted an unstable red-purple compound, obtained by dissolution the heated mixture of potassium nitrate and iron chips in water [2]. Poggendorf is the first, who documented occurrence of purple coloration in anodic oxidation of Fe electrode in strongly alkaline solutions [3]. In 1897, Moeser gave a detailed description of ferrate(VI), its chemical properties and methods of synthesis [4].

Interest in synthesis methods and application of ferrate(VI) was risen during the twentieth century, especially since 1950. Many possible applications of ferrate(VI) as a strong oxidizing agent, coagulant, flocculent and effective disinfectant were tested and confirmed. The biggest advantage of ferrate(VI) is an ability of application in the environment protection, in the wastewater treatment of different origin and composition, as an environmentally friendly oxidizing agent $[5,6,7]$.

One of the possible methods for removal the heavy metal ions from the aqueous medium is application of ferrate(VI), an envi-

\footnotetext{
* Sanitary Medical School of Applied Sciences “Visan “, Tošinbunar 7a, Belgrade, Serbia

** IHIS Techno-experts, Research and Development Center, Batajnički put 23, Belgrade, Serbia, e-mail:mimosa@eunet.rs

*** University "Union Nikola Tesla", Faculty of Ecology and Environmental Protection, Cara Dušana 62-64, Belgrade, Serbia

**** The work was financially supported by the Ministry of Education, Science and Technological Development of the Republic of Serbia, within the Projects TRp 34025 and TRp 31080.
} 
ronmentally friendly oxidant, coagulant and disinfectant. Due to the suitable physical and chemical properties of ferrate(VI), such as high oxidation potential, which is $2.2 \mathrm{~V}$ in acidic conditions, and $0.7 \mathrm{~V}$ in alkaline conditions, forming of the oxygen by oxidation of water, and high capability of coagulation of iron (III) hydroxide, the reduction product of ferrate(VI). Ferrate(VI) hals been proved to be a very efficient and environmentally friendly oxidant, disinfectant and coagulation agent in a variety of application areas. Ferrate(VI) can be produced by the chemical or electrochemical synthesis. Ferrate(VI), produced by the electrochemical synthesis, has many advantages compared to the chemically synthesized ferrate(VI) $[8,9]$ such as: simplicity, lower consumption of chemicals, non-toxic products and exceptional purity of the obtained ferrate(VI). Moreover, the electrochemically produced ferrate(VI) has no instability problem and needs no transportation, and due to the ecological advantages, it can be implemented in wastewater treatment practice, in situ. Also, as a strong oxidizing agent, ferrate(VI) decomposes the complexes of organic compounds with heavy metal ions, which could hinder the efficient coagulation and removal of heavy metal ions from solution and avoid the formation of toxic byproducts, which is often a side effect of conventional methods [10].

Wastewater from the mining and metallurgical processes is characterized by the low $\mathrm{pH}$ value and high concentrations of sulfates, heavy metals and some nonmetals. The heavy metals load is of greater concern than the acidity in the terms of environmental damage. Heavy metals are generally considered those whose density exceeds $5 \mathrm{~g} / \mathrm{cm}^{3}$. Most of elements that falls into this category are highly water soluble, wellknown toxics and carcinogenic agents. Consequence of discharge the untreated mine wastewater in the environment are reflected in aq long-term contamination of soils to which the mine water come in contact and accumulation of heavy metals therein, entering the mine wastewater into surface water, and mixing the mine wastewater with ground water. Therefore, the hydrometallur- gical wastewater is among the most serious threats to the human population and fauna and flora of the receiving water bodies [11,12].

This work deals with investigation the efficiency of sodium ferrate, $\mathrm{Na}_{2} \mathrm{FeO}_{4}$, obtained by theelectrochemical oxidation, as the coagulation and flocculation agent for the wastewater purification from the electrolytic refining process from the Bor Copper Refinery and Copper Smelter Plant of Mining and Smelting Combine Bor.

Removal of heavy metals from wastewater can be accomplished through various treatment options. Some of the conventional treatment processes for their removal are the ion exchange, chemical precipitation, various adsorption methods and membrane separation process. However, all these methods have their drawbacks, which are primarily reflected in the insufficient level of heavy metals removal, high-energy consumption and formation of toxic products. [13].

Also, in this work, the efficiency dependence of copper sulphide ore leaching from concentrate by the oxidation of copper sulfide and chalcopyrite with ferrate(VI) on the sulphuric acid concentration was investigated. The aim is to explore a possibility of copper sulfide oxidation improvement by reduction the number of technological steps and increasing the efficiency of electrolyte preparation process of the copper electrolytic refinement.

The copper oxide ore is leached only by sulphuric acid to form copper sulphate, see Eq. (1).

$$
\mathrm{Cu}_{2} \mathrm{O}+\mathrm{H}_{2} \mathrm{SO}_{4} \rightarrow \mathrm{CuSO}_{4}+\mathrm{H}_{2} \mathrm{O}
$$

Chalcocite and chalcopyrite ore, on the other hand, can only be leached under the oxidizing conditions with ferric ions or oxygen, see Eqs. (2) - (4).

$$
\begin{gathered}
\mathrm{Cu}_{2} \mathrm{~S}+4 \mathrm{Fe}^{3+} \rightarrow 2 \mathrm{Cu}^{2+}+4 \mathrm{Fe}^{2+}+\mathrm{S}^{0} \\
\mathrm{CuFeS}_{2}+4 \mathrm{H}^{+}+\mathrm{O}_{2} \rightarrow \mathrm{Cu}^{2+}+ \\
+\mathrm{Fe}^{2+}+2 \mathrm{~S}^{0}+2 \mathrm{H}_{2} \mathrm{O} \\
\mathrm{CuFeS}_{2}+4 \mathrm{Fe}^{3+} \rightarrow \mathrm{Cu}^{2+}+5 \mathrm{Fe}^{2+}+2 \mathrm{~S}^{0}
\end{gathered}
$$


The formed elemental sulphur, Eqs. (2) (4), can be oxidized by means of oxygen and partially bacteria to form sulphuric acid which reduces the overall sulphuric acid, required for the leaching process.

The major issue with the leaching of chalcopyrite concentrate in an acidic solution of ferric sulphate at atmospheric pressure and temperatures below $110^{\circ} \mathrm{C}$, is that copper dissolution typically slows down once approximately $30 \%$ of dissolved copper, depending on concentrate. Many authors [14] have concluded that this "passivation" effect is due to the formation a film on the surface that does not allow further reaction to occur, but there is no consensus to the actual composition of this layer. Munoz [15] proposed that a layer of sulphur is formed around a chalcopyrite particle. Formation of elemental sulphur or polysulphides: $\mathrm{XS}_{\mathrm{n}}$, and jarosites $\mathrm{XFe}_{3} \quad\left(\mathrm{SO}_{4}\right)_{2}$ $(\mathrm{OH})_{6}$, where $\mathrm{X}^{+}=\mathrm{Na}, \mathrm{K}, \mathrm{Rb}, \mathrm{NH}_{4}, \mathrm{H}_{3} \mathrm{O}$, $\mathrm{Ag}, \mathrm{Tl}$, causes a passivation of chalcopyrite concentrate. The metal deficient sulphides, and elemental sulphur are the prime candidates for any concentrate leaching passivation. [16,17]

Obviously, formation of an insoluble sulphur layer or its compounds may slow down or prevent copper copper from con- centrate in the absence of strong oxidizing substance in the leaching process, particularly in the absence of oxidizing agents. Ferrate(VI), as a strong oxidizer, has shown the ability to oxidize sulphide and sulphur [18], so the aim of this research was to explore the feasibility of ferrate(VI) application as an oxidizer in the process of copper sulphide ore leaching from concentrate.

\section{EXPERIMENTAL}

\section{Electrochemical Synthesis of $\mathrm{Na}_{2} \mathrm{FeO}_{4}$ Solution}

Solution of $\mathrm{Na}_{2} \mathrm{FeO}_{4}$ was obtained in the process of electrochemical synthesis. The process of electrochemical synthesis of an alkaline solution of ferrate(VI) was based on a transpassive anodic dissolution of the iron alloys (3\% Si, C) in $10 \mathrm{M}$ $\mathrm{NaOH}$ solution at a constant current of $1 \mathrm{~A}$ for a period of 1 hour, in accordance with the previous studies [19]. All measurements were performed at room temperature $\left(25 \pm 1^{0} \mathrm{C}\right)$. This was carried out in a laboratory facility for electrochemical synthesis of ferrate(VI), (Fig. 1 and Fig. 2) consisting of a two-part flow-through electrochemical cell [20].

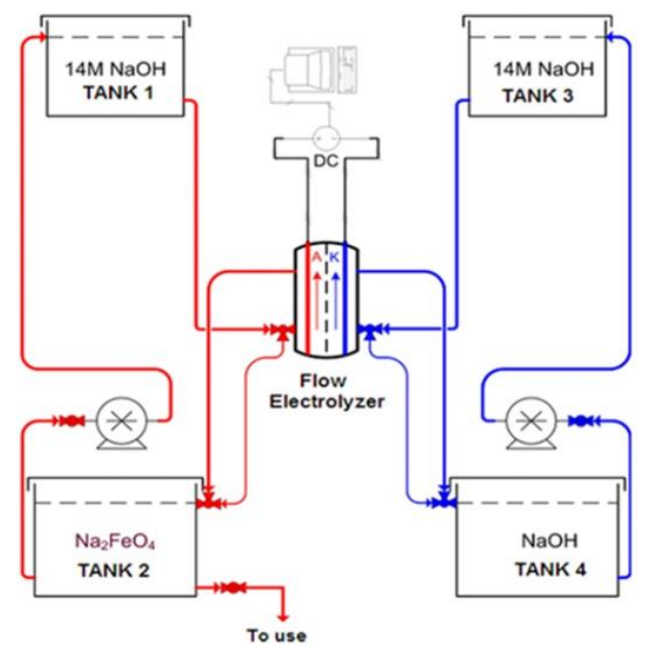

Figure 1 Scheme of the pilot plant for the electrochemical synthesis of ferrate(VI) 


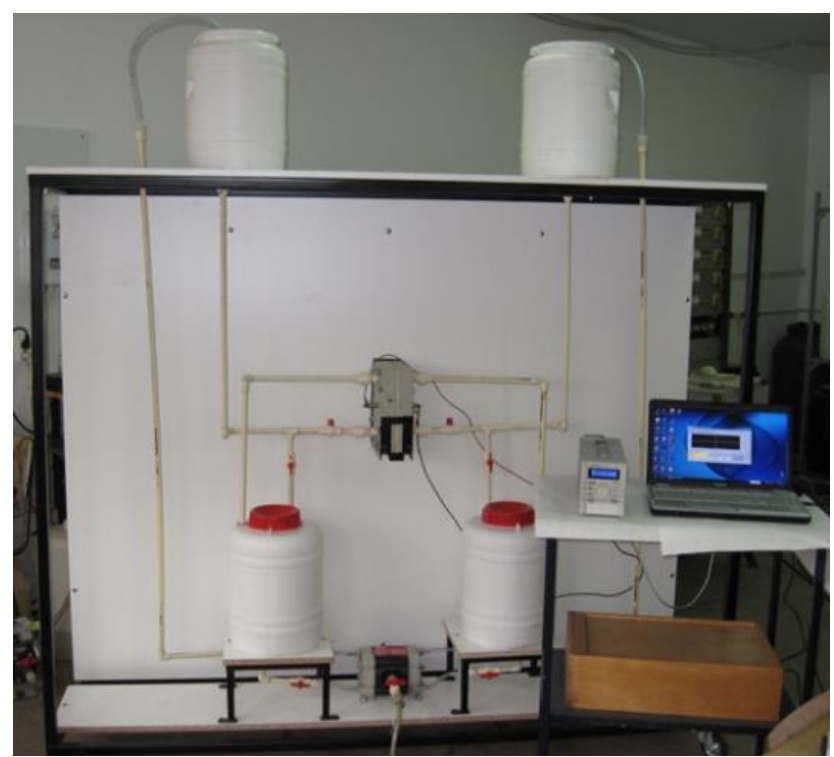

Figure 2 Pilot plant for the electrochemical synthesis of ferrate(VI)

\section{Waste Water from the Electrolytic Refining Process in RTB Bor}

Waste water sample from the electrolytic refining process in RTB Bor is characterized as a highly acidic water $(\mathrm{pH}=0)$ with a light blue color (Fig. 1a) and content in Table 1. The wastewater samples $(200 \mathrm{ml})$ were treated first with $6 \mathrm{ml}$ of $10 \mathrm{M} \mathrm{NaOH}$ solution (p.a. NaOH, "Centrohem" Stara Pazova, Serbia) in order to show a difference between the treatment with $\mathrm{Na}_{2} \mathrm{FeO}_{4}$. After this step, $6 \mathrm{ml}$ of $10 \mathrm{M} \mathrm{NaOH}$ solution with different quantities of $\mathrm{Na}_{2} \mathrm{FeO}_{4}$ were added (2 $\mathrm{mg}, 5 \mathrm{mg}, 15 \mathrm{mg}$ and $20 \mathrm{mg}$ ) as a target to investigate the influence of ferrate(VI) on removal of heavy metals $(\mathrm{Cu}$ and $\mathrm{Fe})$ from the waste water solution. Value of $\mathrm{pH}$ was increased with the addition of ferrate(VI) from 11 to 14 . The treatment of waste water samples was carried out using the Jar test equipment with a four-stirrer unit (Velp
JLT4, Italy). The mixing rate was at first 300 rpm for 10 minutes, and then $160 \mathrm{rpm}$ for 20 minutes. After $30 \mathrm{~min}$, filtering was performed by the vacuum filtration on the Buchner funnel. Chemical analysis of the obtained solutions was carried by the Atomic absorption spectrophotometry analytical technique.

\section{Wastewater from the Copper Smelter Plant of the Mining and Smelting Combine Bor}

The stock solution of synthetic hydrometallurgical, used in the experiment, was synthesized according to the composition and characteristics of a real wastewater from the Copper Smelter Plant of Mining and Smelting Combine Bor, Table 2. 
Table 1 Content of elements in waste water solution from the electrolytic refining operation

\begin{tabular}{|c|c|c|}
\hline Element & Unit & $\begin{array}{c}\text { Effluent from the electrolytic } \\
\text { refining process }\end{array}$ \\
\hline $\mathrm{Al}$ & $\mathrm{mg} / \mathrm{dm}^{3}$ & 7 \\
\hline $\mathrm{Sb}$ & $\mathrm{mg} / \mathrm{dm}^{3}$ & $<1$ \\
\hline As & $\mathrm{mg} / \mathrm{dm}^{3}$ & 4 \\
\hline $\mathrm{Cd}$ & $\mathrm{mg} / \mathrm{dm}^{3}$ & $<1$ \\
\hline $\mathrm{Ca}$ & $\mathrm{mg} / \mathrm{dm}^{3}$ & 64 \\
\hline $\mathrm{Cr}$ & $\mathrm{mg} / \mathrm{dm}^{3}$ & $<1$ \\
\hline $\mathrm{Co}$ & $\mathrm{mg} / \mathrm{dm}^{3}$ & $<1$ \\
\hline $\mathrm{Cu}$ & $\mathrm{mg} / \mathrm{dm}^{3}$ & 698 \\
\hline $\mathrm{Fe}$ & $\mathrm{mg} / \mathrm{dm}^{3}$ & 25.8 \\
\hline $\mathrm{Pb}$ & $\mathrm{mg} / \mathrm{dm}^{3}$ & $<1$ \\
\hline $\mathrm{Mg}$ & $\mathrm{mg} / \mathrm{dm}^{3}$ & 18 \\
\hline $\mathrm{Mn}$ & $\mathrm{mg} / \mathrm{dm}^{3}$ & $<1$ \\
\hline $\mathrm{Ni}$ & $\mathrm{mg} / \mathrm{dm}^{3}$ & 12.2 \\
\hline $\mathrm{Se}$ & $\mathrm{mg} / \mathrm{dm}^{3}$ & $<1$ \\
\hline $\mathrm{Na}$ & $\mathrm{mg} / \mathrm{dm}^{3}$ & 11 \\
\hline $\mathrm{V}$ & $\mathrm{mg} / \mathrm{dm}^{3}$ & $<1$ \\
\hline $\mathrm{Zn}$ & $\mathrm{mg} / \mathrm{dm}^{3}$ & 1.6 \\
\hline $\mathrm{Ag}$ & $\mathrm{mg} / \mathrm{dm}^{3}$ & $<1$ \\
\hline $\mathrm{Bi}$ & $\mathrm{mg} / \mathrm{dm}^{3}$ & $<1$ \\
\hline $\mathrm{Hg}$ & $\mathrm{mg} / \mathrm{dm}^{3}$ & 0.001 \\
\hline $\mathrm{Cl}^{-}$ & $\mathrm{mg} / \mathrm{dm}^{3}$ & 10.21 \\
\hline $\mathrm{SO}_{4}{ }^{2-}$ & $\mathrm{mg} / \mathrm{dm}^{3}$ & 18563.3 \\
\hline
\end{tabular}

Table 2 Characteristics of the real wastewater sample from

the Copper Smelter Plant of Mining and Smelting Combine Bor

\begin{tabular}{|l|c|c|}
\hline \multicolumn{1}{|c|}{ Parameter } & \multirow{2}{*}{ Unit } & August 2012. \\
\cline { 3 - 3 } & & Average \\
\hline Temperature & ${ }^{\circ} \mathrm{C}$ & 25 \\
\hline $\mathrm{pH}$ & & 0.1 \\
\hline Acid content & $\%$ & 3.8 \\
\hline & $\mathrm{g} / \mathrm{dm}^{3}$ & 38.9 \\
\hline Dissolved metals & & \\
\hline $\mathrm{Cu}$ & $\mathrm{g} / \mathrm{dm}^{3}$ & 1.8 \\
\hline $\mathrm{As}$ & $\mathrm{g} / \mathrm{dm}^{3}$ & 0.1 \\
\hline $\mathrm{Sb}$ & $\mathrm{g} / \mathrm{dm}^{3}$ & 0.0008 \\
\hline $\mathrm{Se}$ & $\mathrm{g} / \mathrm{dm}^{3}$ & 0.361 \\
\hline
\end{tabular}

Besides the heavy metals and $\mathrm{Se}$, the sulphate and nitrate ions $\left(\mathrm{c}\left(\mathrm{H}_{2} \mathrm{SO}_{4}\right)=1.770\right.$ $\left.\mathrm{mol} / \mathrm{dm}^{3} \mathrm{i} \mathrm{c}\left(\mathrm{HNO}_{3}\right)=0.001286 \mathrm{~mol} / \mathrm{dm}^{3}\right)$ are present in waste water. For the stock solu- tion synthesis of the synthetic wastewater with the same characteristics and composition as the sample of real water, the following chemicals of p.a. quality were used: 
$\mathrm{CuSO}_{4}$ x $5 \mathrm{H}_{2} \mathrm{O}, \mathrm{As}_{2} \mathrm{O}_{3}, \mathrm{Sb}_{2} \mathrm{O}_{3}, \mathrm{SeO}_{2}, \mathrm{H}_{2} \mathrm{SO}_{4} \mathrm{i}$ $\mathrm{HNO}_{3}$.

In the second stage of treatment, four samples from the previous stage were treated by $\mathrm{Na}_{2} \mathrm{FeO}_{4}$ in the molar ratios $\mathrm{M}: \mathrm{Fe}(\mathrm{VI})$ $=1: 2 ; 1: 4 ; 1: 8 ; 1: 12$, while the fifth sample remained untreated. The second stage of treatment was carried out at room temperature $\left(25^{\circ} \mathrm{C}\right)$, stirred for 30 minutes using the Jar test with a four-unit stirrer (Velp JLT4) at speed of $300 \mathrm{rpm}$ and for $1 \mathrm{~h}$ at speed of $100 \mathrm{rpm}$. After $24 \mathrm{~h}$ of precipitation, the treated samples were filtered through a filter with pore size of $0.20 \mu \mathrm{m}$. The changes in heavy metals and $\mathrm{Se}$ concentrations, treated by $\mathrm{NaOH}$ and $\mathrm{Na} 2 \mathrm{FeO} 4$, were determined analyzing the treated samples using an ICP ThermoiCAP Q device.

\section{Oxidation of Copper Sulfide and Chalcopyrite with Ferrate(VI)}

For the purpose of oxidation the copper sulfide and chalcopyrite with ferrate(VI), the chalcocite and chalcopyrite copper ore concentrates $(22.66 \% \mathrm{Cu}, 34.74 \% \mathrm{~S}$, $29.80 \% \mathrm{Fe}, 7.47 \% \mathrm{SiO}_{2}, 11.36 \% \mathrm{H}_{2} \mathrm{O}$ and $1.93 \% \mathrm{Al}_{2} \mathrm{O}_{3}$ ) were used as the experimental sample. In sample of $2.1 \mathrm{~g}$, the total sulphur content in a form of sulphide was $0.48 \mathrm{~g}, 0.0149 \mathrm{~mol} \mathrm{~S}$, and copper $0.73 \mathrm{~g}$, $0.0115 \mathrm{~mol} \mathrm{Cu}$, the quantity of ferrate(VI) addition is calculated according to the stoichiometry of sulphur oxidation using sodium ferrate(VI). Sodium ferrate(VI) has been electrochemically produced according to earlier reported procedure $[19,20]$.

In a laboratory beaker sample of $2.1 \mathrm{~g}$, the copper ore concentrate is mixed in to $0.5 \mathrm{dm}^{3}$ of demineralized water with a laboratory magnetic stirrer, with the final $\mathrm{pH}$ value 5.75. In such mixture $200 \mathrm{ml}$ of 20 $\mathrm{g} / \mathrm{dm}^{3} \mathrm{Na}_{2} \mathrm{FeO}_{4}$ in $10 \mathrm{M} \mathrm{NaOH}$ solution was added in small portions with intensive stirring, $300 \mathrm{~min}^{-1}$, and later stirring is continued with low speed, $30 \mathrm{~min}^{-1}$. After this operation, the $\mathrm{pH}$ of solution was 14 , and visible flakes of pale blue colored cupric and brown-orange colored ferric hydroxides was clearly visible. The end of reaction was determined spectroscopically
(UV-VIS spectrophotometer Shimadzu model UV-1800) following intensity of absorbance peak at $510 \mathrm{~nm}$ characteristic for $\mathrm{Fe}^{6+}$.

In the course of copper and iron separation from insoluble residue, the acidification of solution is achieved adding the 2:1 mixture of water and concentrated sulphuric acid to convert copper and iron hydroxides into the soluble sulphates. The $\mathrm{pH}$ value was adjusted below 2 . After sedimentation of insoluble particles, a greenish solution was filtered through double black labeled filter paper. The $\mathrm{Cu}$ and $\mathrm{Fe}$ content in filtrate was analyzed by a visible $\mathrm{Cu}$ and Fe spectrophotometry (UV-VIS spectrophotometer Shimadzu model UV-1800) and iodometric titration of copper. The iodometric titration was used for the quantitative determination of copper content in filtrate. As $\mathrm{Fe}^{3+}$ ions oxidize iodide, iron(III) present in filtrate is converted to $\mathrm{FeF}_{\mathrm{n}}^{(3-\mathrm{n})+}$ complex with $\mathrm{NaF}$ to avoid a positive error in copper determination.

\section{RESULTS AND DISCUSSION}

\section{Waste Water from the Electrolytic Re- fining Process in RTB Bor}

Due to a high concentration of $\mathrm{Cu}$ and $\mathrm{Fe}_{\text {tot }}$ in effluent $\left(698 \mathrm{mg} / \mathrm{dm}^{3}\right.$ and $25.8 \mathrm{mg} / \mathrm{dm}^{3}$ respectively), the chemical analysis of treated samples with ferrate (VI) was carried out only for this two elements, $\mathrm{Cu}$ and $\mathrm{Fe}_{\text {tot }}$.

Figure 3 shows samples of waste water from the electrolytic refining process, before and after treatment with ferrate(VI). After neutralization with $6 \mathrm{ml}$ of $\mathrm{NaOH}$ solution and adding $2 \mathrm{mg} \mathrm{Na}_{2} \mathrm{FeO}_{4}$, the $\mathrm{pH}$ value was increased to 13 and there was a hardly soluble precipitate formation of light blue color. With the increasing content of ferrate(VI) at $15 \mathrm{mg} \mathrm{Na}_{2} \mathrm{FeO}_{4}$, there were the hardly soluble dark green particles (Figure 3d). After filtration, the filtrate was completely discolored. Black precipitate with large particles (Fig. 3e) was formed after addition of $20 \mathrm{mg}$ $\mathrm{Na}_{2} \mathrm{FeO}_{4}$. 


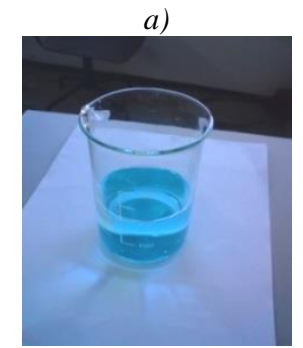

d)

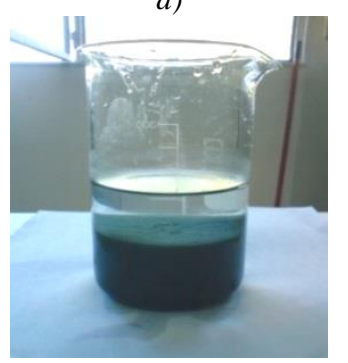

b)

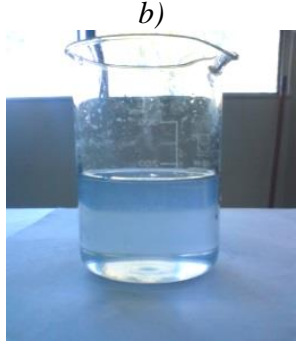

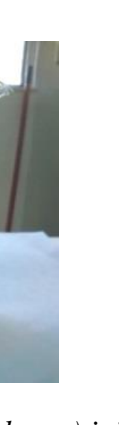
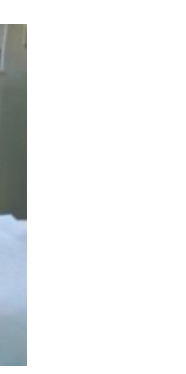

Figure 3 Wastewater samples: a) initial wastewater sample: b) wastewater treated with $2 \mathrm{mg}$ $\mathrm{Na}_{2} \mathrm{FeO}_{4}$ and filtrated; c) wastewater treated with $5 \mathrm{mg} \mathrm{Na}{ }_{2} \mathrm{FeO} \mathrm{O}_{4}$ ferrate(VI) and filtrated; d) wastewater treated with $15 \mathrm{mg} \mathrm{Na}_{2} \mathrm{FeO}_{4}$ ferrate(VI); e) wastewater treated with $20 \mathrm{mg} \mathrm{Na}_{2} \mathrm{FeO}_{4}$

Table 3 and Figure 4 present the con- tion refining operation after treatment with tent of copper and iron in the waste solu- ferrate(VI).

Table 3 Content of $\mathrm{Cu}$ and $\mathrm{Fe}$ in the wastewater refining operation after treatment with $\mathrm{Na}_{2} \mathrm{FeO}_{4}$

\begin{tabular}{|l|c|c|}
\hline \multicolumn{1}{|c|}{ Element } & $\mathbf{C u}, \mathbf{~ m g} / \mathbf{d m}^{3}$ & $\mathbf{F e}_{\text {tot }}, \mathbf{~ m g} / \mathbf{d m}^{\mathbf{3}}$ \\
\hline $6 \mathrm{ml} \mathrm{NaOH}$ & 15 & 0.3 \\
\hline $6 \mathrm{ml} \mathrm{NaOH}+2 \mathrm{mg} \mathrm{Na}_{2} \mathrm{FeO}_{4}$ & 16 & 0.6 \\
\hline $6 \mathrm{ml} \mathrm{NaOH}+5 \mathrm{mg} \mathrm{Na} \mathrm{FeO}_{4}$ & 2.6 & 0.6 \\
\hline $6 \mathrm{ml} \mathrm{NaOH}+15 \mathrm{mg} \mathrm{Na}_{2} \mathrm{FeO}_{4}$ & 0.4 & 0.3 \\
\hline $6 \mathrm{ml} \mathrm{NaOH}+20 \mathrm{mgNa}_{2} \mathrm{FeO}_{4}$ & 0.2 & 0.3 \\
\hline
\end{tabular}

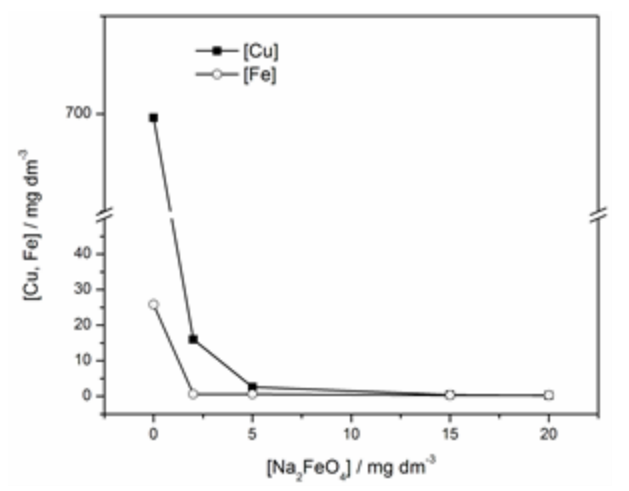

Figure 4 Grafical illustration of $\mathrm{Cu}$ and Fe concentration change after treatment with $6 \mathrm{ml} 10 \mathrm{M} \mathrm{NaOH}$ and $6 \mathrm{ml} 10 \mathrm{M} \mathrm{NaOH}$ with $\mathrm{Na}_{2} \mathrm{FeO}_{4}$ 
It is obvious from the results that the concentration of $\mathrm{Cu}$ in solution after treatment with ferrate (VI) is significantly reduced. The best results were achieved using $6 \mathrm{ml} \mathrm{NaOH}+15 \mathrm{mg} \mathrm{Na} 2 \mathrm{FeO}_{4} \cdot \mathrm{Cu}$ and $\mathrm{Fe}_{\text {tot }}$ concentrations decreased from 698 to 0.4 $\mathrm{mg} / \mathrm{dm}^{3}$, and from 25.8 to $0.3 \mathrm{mg} / \mathrm{dm}^{3}$, respectively.

According to the Ordinance on emission the limit values of pollutants in water and deadlines for their achievement ("Official Gazette of the Republic of Serbia", No. 67/2011), the limit values applicable to the wastewater from production and casting of the non-ferrous metals and byproducts of production and intermediate products before mixing with the other wastewater are: for copper $0.5 \mathrm{mg} / \mathrm{l}$, and iron $3 \mathrm{mg} / \mathrm{l}$.

\section{Wastewater from the Copper Smelter \\ Plant of the Mining and Smelting Combine Bor}

The results of heavy metals and Se removal via precipitation with $\mathrm{NaOH}$ show a high efficiency in $\mathrm{Cu}$ and $\mathrm{Sb}$ removal, a but low efficiency in removal of As and Se, Table 4.

Table 4 Reduction of heavy metals and Se concentrations in the samples of wastewater from the mining industry before and after treatment with $\mathrm{NaOH}$

\begin{tabular}{|c|c|c|c|c|c|}
\hline & $\mathbf{p H}$ & $\mathbf{c}(\mathbf{C u}), \mathbf{m g} / \mathbf{l}$ & $\mathbf{c}(\mathbf{A s}), \mathbf{m g} / \mathbf{l}$ & $\mathbf{c}(\mathbf{S b}), \mathbf{m g} / \mathbf{l}$ & $\mathbf{c}(\mathbf{S e}), \mathbf{m g} / \mathbf{l}$ \\
\hline Before treatment & 0 & 1800 & 100 & 0.8 & 361 \\
\hline $\mathrm{NaOH}$ & 9 & 0.12 & 99.86 & 0.051 & 358.43 \\
\hline Removal, \% & & 99.99 & 0.14 & 93.62 & 0.71 \\
\hline
\end{tabular}

The synthetic wastewater, containing dissolved heavy metals $(\mathrm{Cu}, \mathrm{As}, \mathrm{Sb})$ and Se treated with ferrate(VI), in various molar $\operatorname{ratios}(\mathrm{M}: \mathrm{Fe}(\mathrm{VI})=1: 2 ; 1: 4 ; 1: 8$; $1: 12$ ), has shown a tendency of decreasing concentrations of metals and $\mathrm{Se}$ with increasing the amount of added ferrate(VI). The results of heavy metals and Se removal with $\mathrm{Na}_{2} \mathrm{FeO}_{4}$ from the samples of mining wastewater are shown in Table 5.

Table 5 Reduction of heavy metals and Se concentrations in the samples of wastewater from the mining industry before and after treatment with $\mathrm{BaFeO}_{4}$

\begin{tabular}{|c|c|c|c|c|c|}
\hline $\mathbf{c}\left(\mathbf{N a}_{\mathbf{2}} \mathbf{F e O}_{\mathbf{4}}\right), \mathbf{m o l} / \mathbf{l}$ & $\mathbf{p H}$ & $\mathbf{c}(\mathbf{C u}), \mathbf{m g} / \mathbf{l}$ & $\mathbf{c}(\mathbf{A s}), \mathbf{m g} / \mathbf{l}$ & $\mathbf{c}(\mathbf{S b}), \mathbf{m g} / \mathbf{l}$ & $\mathbf{c}(\mathbf{S e}), \mathbf{~ m g} / \mathbf{l}$ \\
\hline 0 & 0 & 1800 & 100 & 0,8 & 361 \\
\hline $0.0224(1: 2)$ & 9 & $<0.05$ & 30.19 & 0.029 & 351.32 \\
\hline $0.0448(1: 4)$ & 9 & $<0.05$ & 5.12 & 0.024 & 344.65 \\
\hline $0.0896(1: 8)$ & 9 & $<0.05$ & 3.34 & 0.017 & 342.50 \\
\hline $0.1344(1: 12)$ & 9 & $<0.05$ & 2.82 & 0.013 & 339.12 \\
\hline Removal, \% & & 100 & 97.18 & 98.37 & 6.06 \\
\hline
\end{tabular}

The treatment results show a very high efficiency in $\mathrm{Cu}$ removal with $\mathrm{NaOH}$, $99.99 \%$ in the first step of the treatment. Therefore, further removal of $\mathrm{Cu}$ with $\mathrm{Na}_{2} \mathrm{FeO}_{4}$ is not necessary.
Due to a low mobility of As(III) in the aqueous solutions, it cannot be removed from the wastewater with $\mathrm{NaOH}$. However, the As removal with $\mathrm{Na}_{2} \mathrm{FeO}_{4}$ could be up to $97,18 \%$ when $\mathrm{M}: \mathrm{Fe}(\mathrm{VI})$ ratio is $1: 12$ be- 
cause of high oxidation potential of $\mathrm{Fe}(\mathrm{VI})$ which provides $\mathrm{As}(\mathrm{III})$ oxidation to $\mathrm{As}(\mathrm{V})$. Ferrous hydroxide, formed by the reduction of ferrate(VI), as a powerful coagulant removes it easily from solution.

Antimony could be successfully removed in a very high percentage (93.62\%) only using $\mathrm{NaOH}$. Higher efficiency removal of $\mathrm{Sb}$ was achived with $\mathrm{Na}_{2} \mathrm{FeO}_{4}$ $(98.37 \%)$.

Removal of selenium was extremely low in the first stage of treatment, $0.71 \%$. After treatment with $\mathrm{Fe}(\mathrm{VI})$, the removal was more successful $(6.06 \%)$, but not satisfying yet. Higher $\mathrm{M}$ : $\mathrm{Fe}(\mathrm{VI})$ ratio is needed because a large part of $\mathrm{Na}_{2} \mathrm{FeO}_{4}$ is spent on $\mathrm{t}$ oxidation. Further optimization of the treatment conditions should be done in order to improve the removal efficiency of selenium with $\mathrm{Na}_{2} \mathrm{FeO}_{4}$ from aqueous solutions.

\section{Oxidation of Copper Sulfide and Chalcopyrite with Ferrate(VI)}

Absorbance spectra of the intensely reddish colored complex $\mathrm{Cu}\left(\mathrm{NH}_{3}\right)_{4}{ }^{2+}$, formed in the filtrate in reaction of the concentrated aqueous ammonia with $\mathrm{Cu}(\mathrm{II})$, presented in Fig. 5, confirms the presence of $\mathrm{Cu}^{2+}$ ions in filtrate. The absorbance peak at $470 \mathrm{~nm}$ characterizes the presence of $\mathrm{Cu}(\mathrm{II})$. The absorbance spectra of $\mathrm{Fe}(\mathrm{III})$ thiocyanate complex, obtained by the addition of ammonium thiocyanate in filtrate, with the characteristic absorbance peak of $\mathrm{Fe}(\mathrm{III})$ at $474 \mathrm{~nm}$, is presented in Fig. 6.

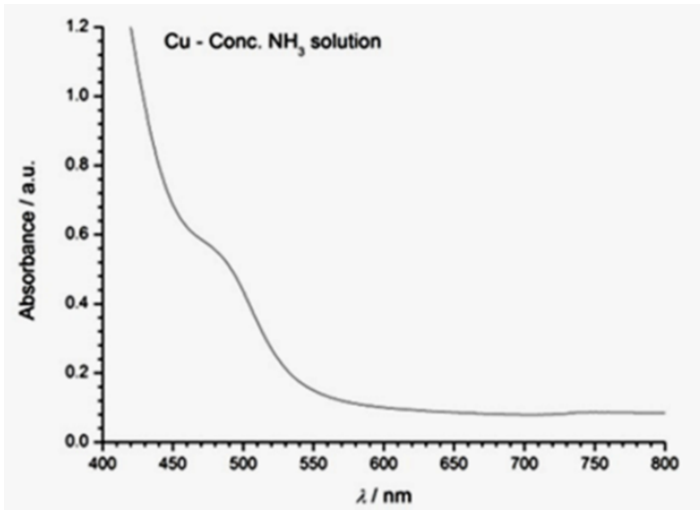

Figure 5 Absorbance spectra of filtrate intensely reddish colored by $\mathrm{Cu}\left(\mathrm{NH}_{3}\right)_{4}{ }^{2+}$ complex

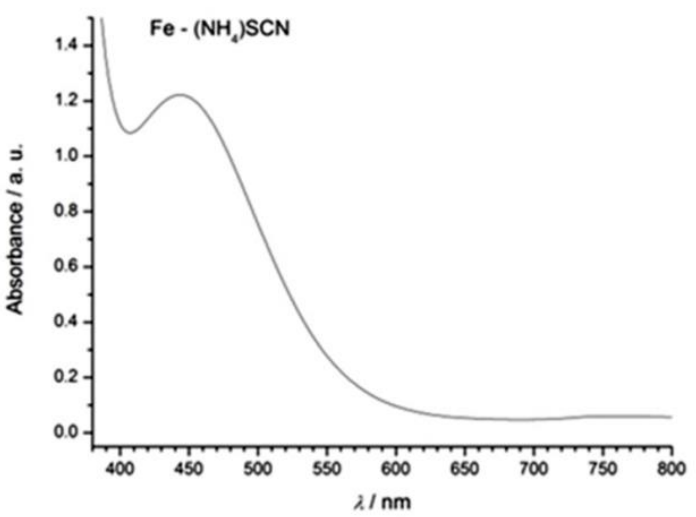

Figure 6 Absorbance spectra of filtrate intensively red colored by $\mathrm{Fe}(I I I)$ thiocyanate complex 
Variation of sulphuric acid solution quantity was completed to investigate the influence of acidification on the leaching reaction efficiency.

Table 6 Copper sulphide ore concentrate leaching with ferrate(VI) efficiency

\begin{tabular}{|c|c|c|c|}
\hline $\begin{array}{c}\mathbf{V}_{\text {Sulphuric acid, }} \\
\mathbf{m l}\end{array}$ & $\begin{array}{c}\text { Time of ferrate(VI) reaction } \\
\text { minutes }\end{array}$ & $\mathbf{C}_{\mathbf{C u}}, \mathbf{g ~ d m}^{\mathbf{- 3}}$ & Efficiency \\
\hline 50 & 90 & 0.52 & 0.71 \\
\hline 100 & 50 & 0.62 & 0.85 \\
\hline 150 & 30 & 0.69 & 0.945 \\
\hline
\end{tabular}

The end of reaction was d spectroscopically determined following the intensity of absorbance peak at $510 \mathrm{~nm}$ characteristic for $\mathrm{Fe}^{6+}$.

$$
\begin{aligned}
& 2 \mathrm{FeO}_{4}^{2-}+\mathrm{Cu}_{2} \mathrm{~S}+4 \mathrm{H}_{2} \mathrm{O} \rightarrow \mathrm{Cu}_{2} \mathrm{O}+2 \mathrm{Fe}(\mathrm{OH})_{3}+\mathrm{SO}_{3}^{2-}+2 \mathrm{OH}^{-} \\
& \mathrm{FeO}_{4}^{2-}+\mathrm{S}+4 \mathrm{H}_{2} \mathrm{O} \rightarrow \mathrm{SO}_{4}^{2-}+\mathrm{Fe}(\mathrm{OH})_{3}+\mathrm{OH}^{-}
\end{aligned}
$$

The results presented in Table 6 obviously confirm a positive effect of the reaction solution acidification on the copper recovery efficiency from the chalcocite and chalcopyrite ore concentrate in presence of ferrate(VI). The acidification of reaction solution provokes the increase of redox potential of ferrate(VI) and its oxidative power, so speeding the copper sulphide oxidation reaction, reaction (5). Also, ferrate(VI) suppresses the formation of passive layer on the chalcocite and chalcopyrite ore particles by polysulphide-sulphide and sulphur oxidation which could be accumulated on its surface in the leaching process.

\section{CONCLUSION}

Iron(VI), known as ferrate, is a powerful oxidant, coagulant and flocculent and its reactions with pollutants are relatively fast with formation the non-toxic by-products. This work concluded that a high $\mathrm{Cu}$ and $\mathrm{Fe}$ removal efficiency with ferrate(VI) was attributed to a comprehensive effect of $\mathrm{Fe}(\mathrm{VI})$ together with its reduced forms and alkaline environment. The aim of this paper was to investigate the possibility of heavy metals and Se removal from the hydro- metallurgical wastewater with $\mathrm{Na}_{2} \mathrm{FeO}_{4}$. It has been shown that the removal of heavy metals with $\mathrm{Na}_{2} \mathrm{FeO}_{4}$ in aqueous solutions can be possible up to: $100 \%$ for $\mathrm{Cu}, 97.18$ $\%$ for $\mathrm{As}, 98.37 \%$ for $\mathrm{Sb}, 6.06 \%$ for $\mathrm{Se}$ using ferrate(VI) in the ratio $\mathrm{M}: \mathrm{Fe}(\mathrm{VI})=$ $1: 12$. By the use of larger amounts of ferrate(VI), more efficient removal of heavy metals could be reached requiring further optimization of the treatment process.

The investigation has shown a clear positive influence of ferrate(VI) on the rate and efficiency of copper sulphide ore leaching reaction, as the result of copper sulphide particles surface passivation pro-cess suppression. The increase of sulphuric acid concentration in a reaction pot speeds up the leaching process and increase its efficiency due to the ferrate(VI) redox potential growth in acid solutions

\section{REFERENCES}

[1] J.W. Mellor, A Comprehensive Treatise on Inorganic and Theoretical Chemistry, Longmans, Green \& Co., London, (1924), p.929-937.

[2] G. E. Stahl, Opusculum ChimicoPhysico - Medium, Halae Magdeburgiae, (1715), p.742. 
[3] J.C. Poggendorff, Annalen der Physik und Chemie, 130 (1841) 161-191.

[4] L. Moeser, J. Prakt. Chem. 56 (1897) 425.

[5] J.Q. Jiang, Research Progress in the Use of Ferrate(VI) for the Environmental Remediation, J. Hazard. Mater., 146 (2007) 617-623.

[6] V.K. Sharma, Potassium Ferrate(VI): An Environmentally Friendly Oxidant, Adv. Environ. Res., 6 (2) (2002) 143-156.

[7] Y. Lee, J. Yoon, U. Von Gunten, Kinetics of the Oxidation of Phenols and Phenolic Endocrine Disruptors During Water Treatment with Ferrate (Fe(VI)), Enviton. Sci. Technol., 39 (2005) 8978-8984.

[8] Wang H., Liu Y., Zeng F., Song S., Electrochemical Synthesis of Ferrate (VI) by Regular Anodic Replacement. Int. J. Electrochem. Sci., 10(2015) 7966 -7976,.

[9] Nikolić Bujanović Lj., Čekerevac M., Vojinović-Miloradov M., Jokić A., Simičić M., A Comparative Study of Iron-Containing Anodes and their Influence on Electrochemical Synthesis of Ferrate(VI), Journal of Industrial and Engineering Chemistry, 18(2012) 1931-1936.

[10] Lim M. and Kim M. J., Effectiveness of Potassium Ferrate $\left(\mathrm{K}_{2} \mathrm{FeO}_{4}\right)$ for Simultaneous Removal of Heavy Metals and Natural Organic Matters from River Water, Water Air and Soil Pollution, 211(2010)(1-4), 313-322,.

[11] Babel S. and T.A. Kurniawan,Cr (VI) Removal from Synthetic Wastewater Using Coconut Shell Charcoal and Commercial Activated Carbon Modified with Oxidizing Agents and/or Chitosan Chemosphere, 54(7)(2004) p. 951- 967
[12] Kržanović D., Ljubojev M., Jovanović I., Vušović N., An Analysis the Effects of Changes in Price of Metal and Operating Costs to the Profit in Exploitation the Copper Ore Deposits, A Case Study: Copper Mine Majdanpek, Serbia, Mining \& Metallurgy Engineering Bor, (2017) No.3-4,

[13] Grosse, D.W., A Review of Alternative Treatment Processes for Metal Bearing Hazardous Waste Streams,J. Air Pollut. Control Assoc., 36 (5), (1986)603-614

[14] Djurdjevac-Ignjatovic L., Ignjatovic D., Ljubojev M., Mitrovic M., Mining and Metallurgy Engineering Bor, Change the Uniaxial Compressive Strength of Paste Backfill Depending on Change the Parameter (2016), 1, p. $17-24$

[15] MunozP., Reaction Mechanism for the Acid Ferric Sulphate Leaching of Chalcopyrtie, Metallurgical and Material Transactions, 10B (1979) 149-158.

[16] Córdoba E., Leaching of Chalcopyrite with Ferric Ion. Part I: General Aspects Hydrometallurgy, 93(2008) 88-96.

[17] Dixon D., A Novel GalvanicallyAssisted Atmospheric Leaching Technology for Copper Concentrates, Canadian Metallurgical Quarterly, 47(2008) 327-336.

[18] Sharma V.K., Oxidation of Inorganic Contaminants by Ferrates (VI, V, And IV) - Kinetics and Mechanisms: A Review, Journal of Environmental Management 92 (2011) 1051-1073.

[19] Čekerevac M. I., Nikolić-Bujanović Lj. N., Jokić A. B., Simičić M. V., Investigation the Electro-Chemical metyhod of Ferrate Syynthesis, Part 2: 
Optimization the Parameters of the Electrochemical Synthesis Process of Ferrate and the Method of Analytical Process Control, Hemijska industrija 64 (2), (2010)111-119 (in Serbian)
[20] Nikolić Bujanović Lj., Čekerevac M. Tomić M., Zdravković M., Ibuprofen Removal from Aqueous Solution by In-Situ Electrochemically Generated Ferrate (VI): Proof-of-Principle, Water Science and Technology, 73, (2)(2016) 389-395. 